Crop Breeding and Applied Biotechnology 12: 52-59, 2012

Brazilian Society of Plant Breeding. Printed in Brazil

\title{
ARTICLE
}

\section{Meiotic behavior of wild Caricaceae species potentially suitable for papaya improvement}

\author{
Emanuelli Narducci da Silva ${ }^{1}$, Monique Freitas Neto ${ }^{1}$, Telma N. S. Pereira ${ }^{1 *}$ and Messias G. Pereira ${ }^{1}$
}

Received 28 July 2009

Accepted 23 May 2011

\begin{abstract}
The purpose of this study was to evaluate the meiotic behavior and determine the meiotic index and pollen viability of representative plants of the wild species V. goudotiana, V. quercifolia and J. spinosa. Meiotic analysis confirmed that the species are diploid and have 18 chromosomes. Meiosis was partially normal, since some abnormalities, e.g, sticky and lagging chromosomes, precocious segregation, lack of synchrony, and disturbances in the spindle fibers were observed. These abnormalities resulted in post-meiotic products (monads, dyads, triads, and polyads) that probably contributed to the meiotic index of $85.7 \%$ (V. goudotiana) to $95.9 \%$ (J. spinosa); significant variation was observed in the species V. goudotiana. The pollen viability of $68.0 \%$ (V. goudotiana) to $96.0 \%$ (J. spinosa) was reasonably good in these wild species. Crossings in breeding programs involving $\mathrm{V}$. goudotiana should therefore be carefully planned, since part of the gametes of this species is unviable.
\end{abstract}

Key words: Vasconcellea goudotiana, Vasconcellea quercifolia, Jacaratia spinosa, meiosis, meiotic index.

\section{INTRODUCTION}

The family Caricaceae contains the genus Cylicomorpha, native to Equatorial Africa, and the genus Carica, Jacaratia, Jarilla, Horovitzia, and Vasconcellea from South and Central America; the most representative genera of the family are the genera Jacaratia with seven and Vasconcellea with 21 species (Badillo 1971, 2000, 2001).
Some of the major problems of papaya are factors such as susceptibility to mosaic virus and pathogens e.g., the fungus Phytophtora palmivora. Some important traits, e.g., flesh thickness and consistency and skin texture need improvement (Costa and Pacova 2003). Several studies on papaya improvement have been conducted, though mostly focused on intraspecific improvement (Silva et al. 2007, Silva et al. 2008). It is therefore worth mentioning that the wild genera

\footnotetext{
${ }^{1}$ Universidade Estadual do Norte Fluminense, Centro de Ciências e Tecnologias Agropecuárias, Laboratório de Melhoramento Genético Vegetal, Av. Alberto Lamego 2000, Campos dos Goytacazes, 28.013-602, RJ, Brasil. *E-mail: telmasp@uenf.br
} 
Jacaratia and Vasconcellea bear promising characteristics for papaya breeding programs, e..g, disease and cold resistance, among others. Hajjar and Hodgkin (2007) highlight the importance of using wild species for the genetic improvement of cultivated forms, by the introgression of genes of agronomic interest to improve a particular crop.

In terms of species distribution in the genus Jacaratia, the dioecious $J$. spinosa stands out, spread from northern Argentina to Nicaragua. This species with smooth-skinned fruits with firm flesh and resistance to the Papaya ringspot virus (PRSV) (Badillo 1971) has a yet unexplored market potential; in Brazil it is found in residual forests of the southeast (Piratelli et al. 1998).

Vasconcellea species are grown on a small scale, mainly by indigenous peoples of the Andes and Ecuador (Badillo 1971). One of the outstanding species of the genus is $V$. goudotiana, resistant to the fungus Phytophthora palmivora, which destroys the plant root meristem and also causes fruit rot (Costa and Pacova 2003). Recently, Siar et al. (2011) reported success in obtaining an intergeneric hybrid between C. papaya and $V$. quercifolia with resistance to mosaic virus, the main papaya disease.

Since gene introgression occurs via interspecific hybridization, which means that pollen grains must be viable to obtain hybrids, it is important to know the fertilization capacity of the intercrossed species, especially in the case of wild species. A normal meiosis development, which underlies the formation of the male gametophyte, ensures pollen fertility at a satisfactory level. During meiosis, homologous chromosome pairing, the structure formation of the synaptonemal complex, crossing-over events, chiasma formation, as well as the formation process of haploid products can be observed. Several genes act in pre-and post-meiosis (Kaul and Murthy 1985) and may result in abnormal or even unviable pollen grains.

The UENF papaya breeding program, conducted as of 1995, has recently included the species $V$. quercifolia, V. cauliflora, V. monoica, $V$. cundinamarcensis, and $V$. goudotiana in the germplasm collection as possible gene sources for papaya improvement. Since these are exotic species, their performance in the new environment must be assessed. The description and analysis of the wild germplasm of the family Caricaceae can broaden the knowledge on the species and enhance their use in breeding programs.
Based on previous cytogenetic studies on the species Caricaceae (Costa et al. 2008, Damasceno Junior et al. 2010), the purpose of this study was to evaluate the meiotic behavior and estimate the meiotic index and pollen viability of representative plants of the wild species V. goudotiana, V. quercifolia and J. spinosa.

\section{MATERIALAND METHODS}

Seeds of representative accessions of the species V. goudotiana (Accessions HCAR 167, HCAR 168, HCAR 169, and HCAR 170), V. quercifolia (HCAR226), and J. spinosa (HCAR227) were donated by the National Germplasm Repository of the USDA/ARS - Hilo - USA. The seeds were left to germinate, but only the accessions HCAR 167 (V. goudotiana), HCAR 226 ( $V$. quercifolia) and HCAR 227 (J. spinosa) germinated. The plants were grown in a greenhouse on the campus of the State University of Norte Fluminense "Darcy Ribeiro" (UENF) under the management commonly used for papaya. At flowering, five male plants per species were identified and labeled for the study.

For meiotic analysis, 10 buds per plant per species were randomly collected at different developmental stages and fixed in Farmer solution (Berlyn and Miksche 1976) for $24 \mathrm{~h}$ with renewal of the solution during this period, and deep-frozen at $-20{ }^{\circ} \mathrm{C}$ until the slides were prepared. For this, the buds were rehydrated in water at room temperature. The slides were prepared by squashing the anthers in drops of $1 \%$ acetic carmine solution, the debris were removed and the slides sealed for observation. The different meiotic stages were observed, paying particular attention to the prophase I stage and to possible irregularities. Any abnormalities such as lagging chromosomes, sticky chromosomes, and precocious segregation, among others, were registered. The number of chiasmata was also noted and the recombination index was calculated (RI) according to Darlington (1958), where RI $=[\Sigma$ total number of chiasmata $\div$ number of analyzed cells] + value of $n$ (number of the haploid set of the species).

To estimate the meiotic index (MI), ready-to-open flower buds were fixed in an ethanol solution with acetic acid (3:1); after 24 hours the solution was replaced by $70 \%$ ethanol and the buds were stored in the refrigerator. Slides were prepared by the squashing technique, by staining the squashed anthers in a $1 \%$ acetic carmine dye solution. Subsequently, the slides were observed under an optical microscope to count the number of 
normal (tetrad) and abnormal post-meiotic products. Tetrads with four cells of the same size were considered normal and any deviation was considered abnormal (monads dyad, triads, and polyads). Four slides.bud per plant ${ }^{-}$were prepared and 500 cells per slide were counted. The meiotic index (MI) was estimated as the ratio of the total normal tetrads by the total post-meiotic products (Love 1951).

To study pollen viability, a triple dye solution composed of orange $\mathrm{G}$, acid fuchsin and malachite green was used (Alexander 1969). Ten ready-to-open flower buds per plant from each species were placed in $70 \%$ ethanol solution and stored in a refrigerator until slide preparation. The anthers were placed in a drop of dye on the slide and gently crushed to release pollen grains. Then the debris $w$ removed and the slides observed under an optical microscope. Two slides per bud were prepared and 500 pollen grains per slide counted. The pollen grains on each slide were classified in viable and unviable and the grains in each class counted. Pollen grains with redpurple cytoplasm were considered viable and those with green or pollen plasmolyzed cytoplasm non-viable.

After preparing the slides by the different methodologies, they were observed under an optical microscope (Olympus BX 60) and the images captured using Image Pro-Plus (Media Cybenetics, version 5.1). The meiotic index and pollen viability data were subjected to analysis of variance, in a completely randomized design (CRD), each slide representing one replication. The Tukey test was applied at $5 \%$ probability, to the mean of each analyzed variable, using Genes software for the statistical analyses.

\section{RESULTS AND DISCUSSION}

Based on the different stages observed, the diploid nature in the three species was confirmed, with $2 \mathrm{n}=2 \mathrm{x}=18$ chromosomes (Figures 1B, 1C and 1D). Some chromosomes in $V$. goudotiana have regions with another color than the rest of the chromosome; these chromosome regions may indicate the presence of knob (Figure 1A), which are heterochromatin-rich regions that are more intensely stained than the rest of the chromosome (Lamb et al. 2007). In V. goudotiana and $J$. spinosa, the presence of a pair of chromosomes associated to the nucleolus was observed (Figure 1A and $1 \mathrm{~B}$ ), indicating that the nucleolus organizer region (NOR) of these species may be located in this pair. The NOR sites are regions of the $45 \mathrm{~S}$ rDNA sequence (rDNA), largely responsible for nucleolus formation. By the technique of fluorescent in situ hybridization (FISH) with rDNA probes (18S and 5S), Costa et al. (2008) found that the species $V$. goudotiana and $V$. cundinamarcensis have a pair of $5 \mathrm{~S}$ sites, while $C$. papaya has three $5 \mathrm{~S}$ sites, $18 \mathrm{~S}$ probes occurred more frequently in the genus Vasconcellea, of which four sites were observed in $V$. goudotiana, and five in V. cundinamarcensis. Damasceno Junior et al. (2010) also observed one nucleolus-associated pair of chromosomes in C. papaya and V. monoica. These regions are considered cytological markers, which may be in the terminal or interstitial chromosome region, thus generating a secondary constriction and, in the second case, a satellite (Schubert 2007).

The recombination index (RI) was estimated for the species $J$. spinosa and V. goudotiana based on meiotic configurations observed in diakinesis cells; was not possible to estimate the RI of V. quercifolia because of the low cell frequency in prophase I. The RI for J. spinosa was 23.6 and 26.2 for V. goudotiana. Dasmaceno Junior et al. (2010) reported similar RI values to those found in this study for C. papaya and V. monoecious (26.0 and 25.8 respectively). These values can be considered satisfactory, based on a review of the RI of 194 species of 46 genera and 15 angiosperm families, with values ranging from 6.56 to 75.2, with a mean of 26.9 (Koella 1993).

The recombination index is estimated based on the number of chiasmata (Darlington 1958) without taking the chiasma position into account, which can be terminal or interstitial. Terminal chiasmata only have the function of maintaining the physical structure of the bivalent to ensure perfect chromosome segregation, while the interstitial are involved in genetic recombination (Zarchi et al. 1972, Hillel et al. 1973). In an attempt to refine the index, Colombo (1992) proposed another method that takes the chromosome size and the exact chiasma position into consideration, of which the latter is very important for the use of the method. Because of its relevance, regardless of the method, the recombination index has been widely discussed and estimated elsewhere (Forni-Martins 1996, BaptistaGiacomelli et al. 2000). Recombination is a crucial event in genetic improvement for allowing the creation of new allele combinations in the chromosomes of genotypes to be improved (Martinez-Perez and Moore 2008, Wijnker and Jong 2008).

Meiosis was generally normal in the three species, apart from some meiotic abnormalities: lagging 
chromosomes, sticky chromosomes, abnormal spindle fibers, lack of synchrony and occurrence of cytomixis. Lagging chromosomes were observed in metaphase I cells of $V$. quercifolia and V. goudotiana (Figure 1G). The presence of lagging chromosomes can generate unbalanced or aneuploid gametes, since lagging chromosomes can be retained in the cytoplasm, not following the set of chromosomes along the normal cell division process and are eventually eliminated as micronuclei (Kodoru and Rao 1981).

Another anomaly in V. goudotiana cells was the occurrence of sticky chromosomes (Figure 1G). This anomaly, controlled by genetic and environmental factors, consists of chromosome clustering in the cell,
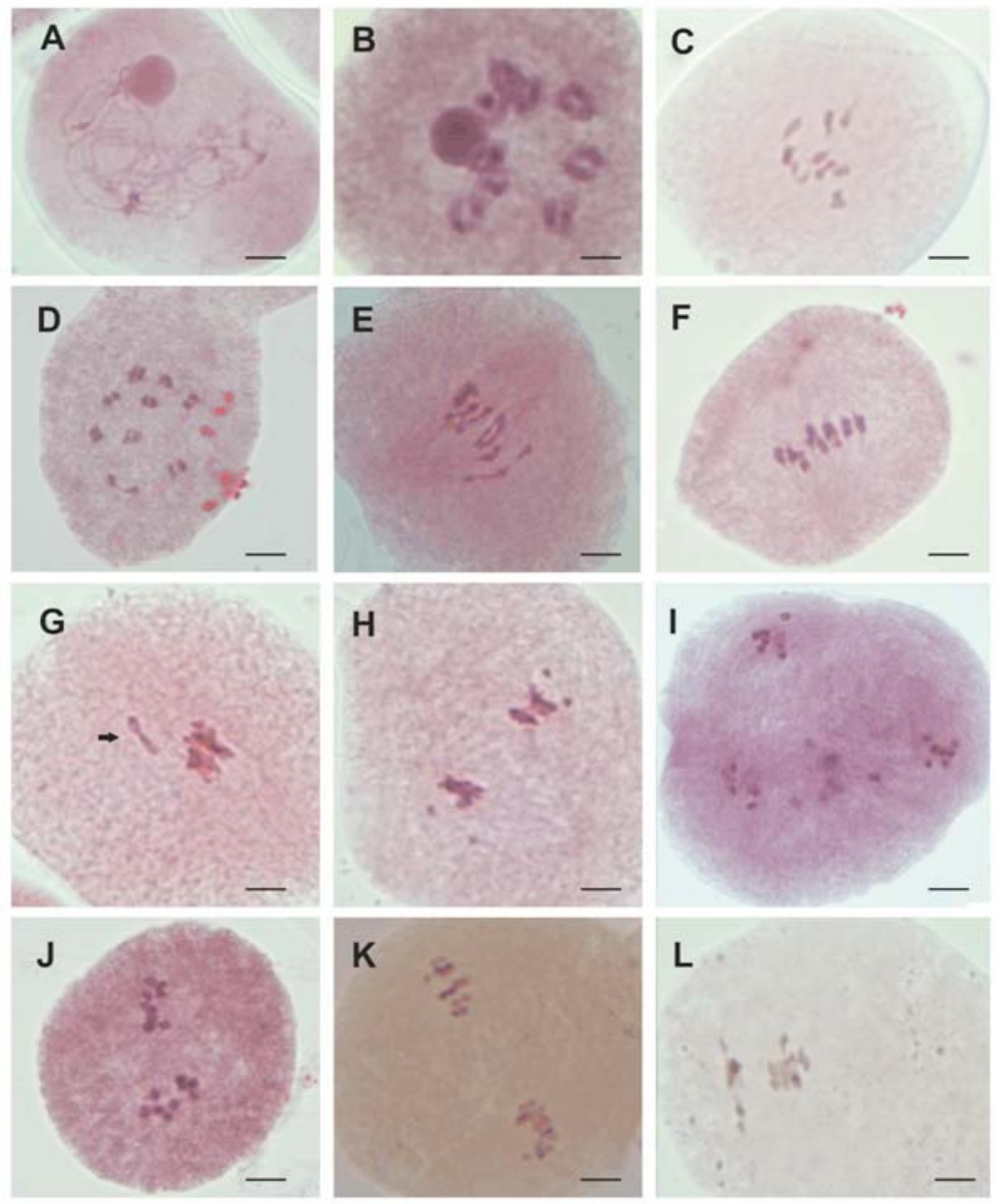

Figure 1. Meiosis in Caricaceas species. A - Prophase I, pachytene substage in V. goudotiana where more condensed chromosomes are observed, some with knobs; B) Diacinese in J. spinosa with nine chromosome pairs, with ring chiasmata C) - Prometaphase in $V$. quercifolia with nine bivalents; D) Diakinesis in J. spinosa showing one chromosome pair with terminal chiasmata (arrow); E)metaphase I in V. goudotiana evidenciando um chromosome pair with terminal chiasmata (arrow); F) Metaphase I in V. quercifolia; G) Metaphase I in V. goudotiana showing a lagging chromosome pair; H) Metaphase II in V. goudotiana with sticky chromosomes and early segregation of one pair in each nucleus. I-Cell in V. goudotiana with irregular multiple spindle fibers; J) Lack of synchrony in a $J$. spinosa cell, with chromosomes of one pole in metaphase II and of the other in anaphase II; K) Metaphase II in V. quercifolia with a lagging chromosome; L) Cytomixis in V. quercifolia. Bars $=5 \mu \mathrm{m}$. 
and can occur at different meiotic stages. Several mutant genes are reported as responsible for the occurrence of sticky chromosomes in plant species. Usually, this anomaly is followed by chromosome fragmentation, anomalies in achromatic spindle fibers, and by abnormal meiosis. Among the environmental factors, temperature and herbicide application can induce this kind of anomaly (Koduru and Rao 1981, Bajpai and Singh 2006). Bajpai and Singh (2006) cited sticky chromosomes as the most frequent abnormality $(21.6 \%-44 \%)$ in commercial papaya varieties.

Another important event observed in cells of both $V$. quercifolia and V. goudotiana was the precocious segregation of some chromosomes (Figure 1H). Studies on mother pollen cells of hermaphrodite and male papaya plants reported the presence of a chromosome pair with precocious segregation compared to the others (Storey 1953, Bajpai and Singh 2006). According to these authors, early chromosome segregation in papaya may be associated with the existence of sex chromosomes. However, in species with small chromosomes, problems of segregation can occur during meiosis (Schubert 2007), which may be the case in Caricacea species, since the average chromosome size of these species is considered small (Damasceno Junior et al. 2009). In addition to these abnormalities, the achromatic spindle fibers of $V$. goudotiana cells were disorganized. Among the spindle fiber anomalies, fibers in $\mathrm{C}$ shape and multiple fibers were observed (Fig. 1I). Both anomalies were reported in Caricaceae species including V. goudotiana (Caetano et al. 2008) and other species such as maize and intergeneric hybrids of cereals (Shamina 2005).

Cytomixis, which is the migration of chromatin via channels or intercellular bridges, in meiocytes located close to each other (Latto et al. 2006) was observed in $V$. quercifolia plants in a dyad (Figure 1L). This anomaly was observed in $V$. monoica cells (Dasmaceno Junior et al. 2010). Although cytomixis was reported in several plant species, its origin is unclear, but chemical factors, pathological conditions, radiation, temperature, mechanical damage, hybridization and polyploidy may influence this phenomenon directly (Pagliarini 2000).

The cytokinesis of the studied species was normal, with the formation of four nuclei at each cell pole that later gave rise to tetrads. In angiosperms, cytokinesis can be simultaneous or successive (Ramanna and Jacobsen 2003). In the three species under study, cytokinesis is simultaneous, i.e., cellularization occurs after telophase II resulting in tetrads and the arrangement is predominantly tetraedal (Figures 2A-C). Abnormal post-meiotic products such as polyads, dyads and triads resulting from the meiotic abnormalities were observed in all three species (Fig. 2 DF). Dyads and triads can produce unreduced gametes $(2 \mathrm{n})$, while the polyads generate unbalanced gametes due to the presence of micronuclei, which generally speaking, are lagging chromosomes. Similar results were reported for other species such as $V$. pubescens (Zerpa 1980), in C. papaya and V. monoica (Damasceno Junior et al. 2010), the most frequent being triads. Caetano et al. (2008) found that the meiotic abnormalities in some $V$. cauliflora and V. cundinamarcensis accessions directly affected the formation of the final meiotic products and had a direct influence on the meiotic index and pollen viability.

Statistical analysis of the meiotic index (MI) and pollen viability of the species was significant at $5 \%$ probability. For the means of both traits, no significant differences were observed between the species by the Tukey test at $5 \%$ probability (Table 1 ). The MI of the species $J$. spinosa, V. quercifolia, V. goudotiana was $95.9 \%, 94.1 \%$ and $85.7 \%$, respectively (Table 1 ) and by the Tukey test of means the differences in the MI were significant between species, and within species differences were observed between $V$. goudotiana plants. The MI of V. goudotiana was beyond the ideal range considering Love (1951), who stated that species with a $\mathrm{MI}<90 \%$ are meiotically unstable and unsuitable for breeding programs based on hybridization. Nevertheless, this value was considered satisfactory in this study since the data were obtained in an environment completely different from the species habitat, the Andean region (Badillo 1971). Therefore, the meiosis of the analyzed plants of the species can be considered satisfactory, although unbalanced gametes are possible. Similar results were reported by Damasceno Junior et al. (2010) for C. papaya and V. monoica, with meiotic indices of $94.84 \%$ and $77.57 \%$, respectively.

The analysis of pollen viability revealed the direct influence of post-meiotic products on the formation of pollen grains (Figs. $2 \mathrm{G}-\mathrm{I}$ ). The estimated viability was high for the species J. spinosa (96\%) and V. quercifolia (90.2\%), but low for $V$. goudotiana (68\%) (Table 1). Statistically, there was no difference between plants of $J$. spinosa and $V$. quercifolia in terms of pollen viability. 
Table 1. Meiotic indexes (MI) and pollen viability (PV) of $J$. spinosa, V. goudotiana and V. quercifolia

\begin{tabular}{|c|c|c|}
\hline Species/Plant & MI (\%) & PV (\%) \\
\hline \multicolumn{3}{|l|}{ J.spinosa } \\
\hline Plant 1 & $93.4 \mathrm{a}^{1}$ & $94.0 \mathrm{a}^{1}$ \\
\hline Plant 2 & $95.8 \mathrm{a}$ & $97.0 \mathrm{a}$ \\
\hline Plant 3 & $95.4 \mathrm{a}$ & $96.0 \mathrm{a}$ \\
\hline Plant 4 & $97.0 \mathrm{a}$ & $95.0 \mathrm{a}$ \\
\hline Plant 5 & $97.8 \mathrm{a}$ & $98.0 \mathrm{a}$ \\
\hline General mean & $95.9 \mathrm{~A}^{2}$ & $96.0 \mathrm{~A}^{2}$ \\
\hline \multicolumn{3}{|l|}{ V. goudotiana } \\
\hline Plant1 & $88.8 \mathrm{a}$ & $85.1 \mathrm{a}$ \\
\hline Plant 2 & $90.2 \mathrm{a}$ & $78.5 \mathrm{a}$ \\
\hline Plant 3 & $84.3 \mathrm{~b}$ & $62.8 \mathrm{~b}$ \\
\hline Plant 4 & $84.3 \mathrm{~b}$ & $48.5 \mathrm{c}$ \\
\hline Plant 5 & $80.4 \mathrm{~b}$ & $64.8 \mathrm{a}$ \\
\hline General mean & 85.7 B & $68.0 \mathrm{~B}$ \\
\hline \multicolumn{3}{|l|}{ V. quercifolia } \\
\hline Plant1 & $92.4 \mathrm{a}$ & $90.0 \mathrm{a}$ \\
\hline Plant 2 & $90.6 \mathrm{a}$ & $88.0 \mathrm{a}$ \\
\hline Plant 3 & $94.4 \mathrm{a}$ & $91.0 \mathrm{a}$ \\
\hline Plant 4 & $97.6 \mathrm{a}$ & $92.0 \mathrm{a}$ \\
\hline Plant 5 & $95.4 \mathrm{a}$ & $90.0 \mathrm{a}$ \\
\hline General mean & $94.1 \mathrm{~A}$ & $90.2 \mathrm{~A}$ \\
\hline
\end{tabular}

${ }^{1}$ Means followed by the same lowercase letter in the column did not differ by Tukey test at $5 \%$ probability

${ }^{2}$ Means followed by the same capital letter in the column did not differ by Tukey test at $5 \%$ probability.

However, in V. goudotiana the plant means differed and pollen viability ranged from $85.1 \%$ to $48.5 \%$, the latter being considered low. This behavior is probably caused by the greater number of meiotic irregularities of this species, resulting in a low MI and low pollen viability. According to Corrêa et al. (2005), meiotic changes should theoretically reflect on pollen viability, since the trait of pollen fertility is intimately related to the success of the meiotic process.

Based on the results of this study, it was concluded that the meiosis of the analyzed plants of the three species ranged from normal to partially irregular. Of the three species, most abnormalities were observed for $V$. goudotiana, but the habitat of this wild species is the highland region, with milder temperatures. Environmental conditions may therefore have affected cell division, as temperature is an important climatic factor in meiosis. These irregularities resulted in anomalous post-meiotic products and low pollen viability for $V$. goudotiana. Thus, for breeding programs involving plants of this species in hybridization, a careful planning of the number of crosses to be performed is necessary, since part of the gametes of this species is unviable.

\section{ACKNOWLEDGEMENTS}

The authors thank FAPERJ (Fundação Carlos Chagas Filho de Amparo à Pesquisa do Estado do Rio de Janeiro) and the National Council for Scientific and Technological Development (CNPq) for financial support and the National Germplasm Repository USDA/ARS - Hilo, USA for the donation of Vasconcelleae seeds.

\section{Comportamento meiótico de espécies silvestres Caricaceae com uso potencial no melhoramento do mamoeiro}

Resumo - Os objetivos desse trabalho foram avaliar o comportamento meiótico, determinar o índice meiótico e a viabilidade polínica de plantas representantes das espécies silvestres V. goudotina, V. quercifolia e J. spinosa. A avaliação da meiose confirmou que as espécies são diplóides com dezoito cromossomos. A meiose foi parcialmente normal já que algumas anormalidades, como cromossomos pegajosos, retardatários, segregação precoce, falta de sincronia e distúrbios nas fibras do fuso foram observadas. Produtos pós-meióticos (tríades, díades, mônades e políades) resultaram dessas anormalidades e provavelmente contribuíram para o índice meiótico que variou de 85,7 \% (V. goudotiana) a 95,9\% (J. spinosa); foi observada variação significativa dentro de V. goudotiana. A viabilidade polínica variou de 68,0 \% (V. goudotiana) a 96,0 \% (J. spinosa) valores satisfatórios considerando que as espécies são silvestres. Assim, sugere-se que em programas de hibridação envolvendo V. goudotiana os cruzamentos devam ser bem planejados, já que parte dos gametas dessa espécie é inviável.

Palavras-chave: Vasconcellea goudotiana, Vasconcellea quercifolia, Jacaratia spinosa, meiose, índice meiótico. 


\section{REFERENCES}

Alexander MP (1969) Differential staining of aborted and nonaborted pollen. Stain Technology 44: 117-122.

Badillo VM (1971) Monografia de la família Caricaceae. Universidad Central de Venezuela, Maracay, 140p.

Badillo VM (2000) Carica L. vs. Vasconcella St.Hil. (Caricaceae) con la rehabilitación de este último. Ernstia 10: 74-79.

Badillo VM (2001) Nota correctiva Vasconcellea St. Hill, y no Vasconcella (Caricaceae). Ernstia 11: 75-76.

Bajpai A and Singh AK (2006) Meiotic behavior of Carica papaya L.; Spontaneous chromosome instability and elimination in important cvs. in North Indian conditions. Cytologia 71: 131-136.

Baptista-Giacomelli FR, Pagliarini MS and Almeida JL (2000) Chiasma frequency, distribution and terminalization in hexaploid oats (Avena sativa L.) Acta Scientiarum 22: 269-273.

Berlyn GP and Miksche JP (1976) Botanical microtechnique and cytochemistry. Iowa State University Press, Iowa, 326p.

Caetano CM, Burbano TCL, Sierra CLS, Tique CAP and Nunes DGC (2008) Citogenética de espécies de Vasconcellea (Caricaceae). Acta Agronômica 57: 241-245.

Colombo PC (1992) A new index for estimating genetic recombination from chiasma distribution data. Heredity 69: 412-415.

Corrêa MGS, Viegas J, Silva JB, Avila PFV, Busato GC and Lemes JS (2005) Meiose e viabilidade polínica na família Araceae. Acta Botânica Brasileira 19: 295-303.

Costa AFS and Pacova BEV (2003) Caracterização de cultivares, estratégias e perspectivas do melhoramento genético do mamoeiro. In Martins DS and Costa AFS (eds.) A cultura do mamoeiro - tecnologia de produção. INCAPER, Vitória, p. 59-102.

Costa FR, Pereira TNS, Hodnett GL, Pereira MG and Stelly DM (2008) Fluorescent in situ hybridization of $18 \mathrm{~S}$ and $5 \mathrm{~S}$ rDNA in papaya (Carica papaya L.) and wild relatives. Caryologia 61: 411-416.

Damasceno Júnior PC, Costa FR, Pereira TNS, Freitas Neto $M$ and Pereira MG (2009) Karyotype determination in three Caricaceae species emphasizing the cultivated form (C. papaya L.). Caryologia 62: 10-15.

Damasceno Júnior PC, Pereira TNS, Freitas Neto M and Pereira MG (2010) Meiotic behavior of Carica papaya and Vasconcellea monoica. Caryologia 63: 229-263.

Darlington CD (1958) Evolution of genetic systems. Inc Publishers, New York, 510p.
Forni-Martins ER (1996) Recombination indices in species of Erythrina L. (Leguminosae, Papilionoideae). Botanical Journal of the Linnean Society 122: 163-170.

Hajjar R and Hodgkin T (2007) The use of wild relatives in crop improvement: a survey of development over the last 20 years. Euphytica 156: 1-13.

Hillel J, Feldman NW and Simchen G (1973) Mating systems and population structure in two closely related species of the wheat groups: III. Chiasma frequency and population structure. Heredity 31: 1-9.

Kaul MLH and Murthy TGK (1985) Mutant genes affecting higher plant meiosis. Theoretical Applied Genetics 70: 449-466.

Kodoru PRK and Rao MK (1981) Cytogenetics of synaptic mutants in higher plants. Theoretical Applied Genetics 59: 197-214.

Koella JC (1993) Ecological correlates of chiasma frequency and recombination index of plants. Biological Journal of the Linnean Society 48: 227-238.

Lamb JC, Weichang Y, Han F and Birchier JA (2007) Plant chromosomes from end to end: telomeres, heterochromotin, and centromeres. Current Opinion in Plant Biology 10: 116-122.

Latto SK, Khan S, Bamotra S and Dhar AK (2006) Cytomixis impairs meiosis and influences reproductive success in Chlorophytum comosum (Thunb) Jacq. - An additional strategy and possible implications. Journal of Bioscience 31: 629-637.

Love RM (1951) Varietal differences in meiotic chromosome behavior of Brazilian wheats. Agronomy Journal 43: 72-76.

Martinez-Perez E and Moore G (2008) To check or not to check? The application of meiotic studies to plant breeding. Current Opinion in Plant Biology 11: 222-227.

Pagliarini MS (2000) Meiotic behavior of economically important plant species: the relationship between fertility and male sterility. Genetics and Molecular Biology 23: 97-102.

Piratelli AJ, Pinã-Rodrigues FCM, Gandara FB, Santos FMG and Costa LGS (1998) Biologia da polinização de Jacaratia spinosa (Aubl) Adc. (Caricaceae) em mata residual do sudeste brasileiro. Revista Brasileira de Biologia 58: 671-679.

Ramanna MS and Jacobsen E (2003) Relevance of sexual polyploidization for crop improvement - a review. Euphytica 133: 3-18.

Shamina NV (2005) Formation of division spindles in higher plant meiosis. Cell Biology International 29: $307-$ 318 . 
Siar SV, Beligan GA, Sajise AJC, Villegas VN and Drew RA (2011) Papaya ringspot virus resistance in Carica papaya via introgression from Vasconcellea quercifolia. Euphytica 181: 159-168.

Silva FF, Pereira MG, Damasceno Junior PC, Pereira TNS, Viana AP, Daher RF, Ramos ECC and Ferreguetti GA (2007) Evaluation of the sexual expression in a segregating $\mathrm{BC}_{1}$ papaya population. Crop Breeding and Applied Biotechnology 7: 16-23.

Silva FF, Pereira MG, Ramos ECC, Damasceno Junior PC, Pereira TNS, Candido APG, Viana AP and Ferreguetti GA (2008) Selection and estimation of genetic gain in segregating generations of papaya. Crop Breeding and Applied Biotechnology 1: 1-8.
Schubert I (2007) Chromosome evolution. Current Opinion in Plant Biology 10: 109-115.

Storey WB (1953) Genetics of the papaya. Journal of Heredity 44:70-78.

Wijnker E and Jong H (2008) Managing meiotic recombination in plant breeding. Trends in Plant Science 13: 640-646.

Zarchi Y, Simchen G, Hillel J and Schaap T (1972) Chiasmata and the breeding system in wild populations of diploid wheats. Chromosoma 38: 77-94.

Zerpa DM (1980) Comportamiento meiótico de la descendencia híbrida producida al transferir el carácter bisexual de $C$. pubescens a $C$. stipulata. Revista de la Faculdad de Agronomia 11: 5-47. 